Apidologie, 1977, 8 (4), 305-319.

\title{
NECTAR COMPOSITION AND MEMBRANE TRANSPORT OF SUGARS AND AMINO ACIDS : A REVIEW ON THE PRESENT STATE OF NECTAR RESEARCH
}

\author{
Ulrich LÜTTGE \\ Institut für Botanik, \\ Technische Hochschule Darmstadt, W-Germany
}

SUMMARY

This review discusses rates of active membrane transport of sugars in nectar secretion in comparison with sugar fluxes in other plant systems. Possible mechanisms of sugar membrane transport are evaluated, namely vectorial group transfer reactions mediated by membrane bound phosphatases and chemi-osmotic coupling to $\mathrm{H}^{+}$-electro-chemical gradients. The chemical composition of nectar is discussed in relation to the secretion mechanism leading to specific sugar elimination and also in relation to the possible evolution of specific amino acid secretion mechanisms.

\section{1. - SPECIFIC AND ACTIVE TRANSPORT OF SUGAR, AN OLD AND NEW PROBLEM IN EXPLANATION OF NECTAR SECRETION AND NECTAR COMPOSITION}

The sensitivity of nectar secretion to metabolic inhibitors strongly suggests an active membrane transport of sugars. Concentration gradients between the phloem sap - i.e. the source of nectar - and the nectar itself rarely have been clearly measured. A consideration of average values suggests, however, that at least in some cases uphill transport must be involved when sugar moves from the phloem via the parenchyma and the secretory cells of nectary glands into the nectar : Average sugar concentrations in the phloem sap range 
from 18 to $30 \%$, those in the nectar from 6 to $60 \%$ or more (e.g. 58-92\% in nectar of dwarf mistletoe Arcenthobium spp. : BREWER et al., 1974). (See review of LüTTGE and Schnepf, 1976, for further references.)

The role of driving forces other than active membrane transport is limited. Invertases in the nectar or in the outer space of the gland surface (ZIMMERMaNN, 1954) can split sucrose into its hexose monomers. This could serve the maintenance of a sucrose concentration gradient driving passive sucrose diffusion. However, invertases would not be sensitive to the energy transfer inhibitors which block nectar secretion. Conversely, sugar metabolism within the gland tissue could be involved as a driving force of secretion. Sugars indeed are subject to metabolic modification as they pass through the secretory tissue. But this is limited. ZIEGLER (1965) has reported that Abutilon nectaries supplied with ${ }^{14} \mathrm{C}$-sucrose labeled in the glucose moiety but not in the fructose moiety secreted nectar with $28 \%$ of the label transferred to the carbon skeleton of fructose, the rest remaining in glucose.

Thus the active membrane transport remains the major driving force. Thermodynamically it is sufficient when this occurs at one site, i.e. at one particular membrane in the tissue, with subsequent passive down-hill diffusion. Of course, thermodynamic principle does not rule out that active uphill transport occurs at more than one site in the system. Schnepf has pointed out in the preceding review of this symposium that symplastic coupling within the system of sieve tubes, companion cells, parenchyma cells, and secretory cells of nectary glands allows many possible sites for active membrane transport : phloem unloading, passage of stalk cells (e.g. in Abutilon), elimination from secretory cells (e.g. trichomes in Abutilon), or the loading of ER and secretion vesicles if granulocrine secretion occurs.

Phloem unloading presumably is not the decisive step. Abutilon nectaries in situ secrete 7 times more sugar than originally present in the gland tissue at the onset of secretory activity (FINDLAY et al., 1971). However, isolated nectaries also can secrete actively.

In Abutilon due to the special structure of the secretory trichome all sugar secreted has to pass the basal stalk cell (GuNNing and Hughes, 1976). This allows evaluations of membrane flux rates on the basis of various assumptions on the secretory surface (fig. 1). Enormous rates of membrane flux would result from the observed nectar volume and concentration if active membrane transport occured only in the stalk cell or in the cap cell of the trichomes. Rates comparable to those observed in other plant systems (table 1) are obtained when it is assumed that the stalk cell is passed by symplastic transport and subsequently the membrane surfaces of all trichome cells contribute to active membrane transport. There are no cell wall protuberances in the trichome cells of Abutilon which would further increase the 
plasmalemma surface and thus reduce the calculated apparent flux rate. In fact, the special structure of the trichome with many small cells leading to a large total cell surface may be an alternative to increasing the surface by formation of cell wall protuberances. An involvement of a large endomembrane surface (e.g. ER) with subsequent granulocrine secretion (see preceding review by SCHNEPF) is, of course, not ruled out by the above consideration.

\begin{tabular}{|c|c|c|}
\hline $\begin{array}{l}\text { ABUTILON } \\
\text { sucrose } \\
\text { secretion }\end{array}$ & $\begin{array}{l}\text { assumption in estima - } \\
\text { tion of active secretory } \\
\text { membrane surface }\end{array}$ & $\begin{array}{l}\text { rate of mem- } \\
\text { brane transport } \\
\mu \mathrm{mol} \mathrm{m}^{-2} \mathrm{~s}^{-1}\end{array}$ \\
\hline $\begin{array}{l}\text { average nectar } \\
\text { volume per tri- } \\
\text { chome: } \\
30 \mu \mathrm{m}^{3} \mathrm{~s}^{-1} \\
\text { (range } 8-80 \text { ) }\end{array}$ & $\begin{array}{l}\text { distal wall of } \\
\text { stalk cell }\end{array}$ & 110 \\
\hline $\begin{array}{l}\text { nectar concen- } \\
\text { tration } Q .4 M \\
\text { (observed up } \\
\text { to } 0.6 \mathrm{M} \text { ) }\end{array}$ & $\begin{array}{l}\text { spherical } \\
\text { apical cell } \\
\text { total trichome plus } \\
\text { apoplastic route } \\
\text { to apex }\end{array}$ & 0.6 \\
\hline
\end{tabular}

FIG. 1. - Rates of sugar membrane fluxes in Abutilon nectaries on the basis of various assumptions on active secretory membrane surface (bold lines in sketches of trichomes). (After data from Findlay and Mercer, 1971; Gunning and Hughes, 1976.)

Flux rates are concentration dependent (table 1). A sugar concentration of $18-30 \%$ in the phloem sap (see above) would be equivalent to a supply of an about 0.5-1 $\mathrm{M}$ sucrose solution to the nectary glands. Even on the basis of such a very high concentration membrane fluxes like 65 or $110 \mu$ mole $\mathrm{m}^{-2} \mathrm{~s}^{-1}$ appear exorbitant and it is most likely that in Abutilon the entire surface of all trichome cells is active in secretion as assumed in the bottom part of Figure 1 . This is supported by cytological and ultrastructural evidence (GUNNING and Hughes, 1976).

\section{2. - MEMBRANE TRANSPORT OF SUGARS}

Two basically different mechanisms may serve active membrane transport of sugars. In nectar research one of them received great attention in the past, the other one has been barely considered hitherto. 
TABLE 1. - Membrane flux rates of sugar transport in various plant systems.

\begin{tabular}{|c|c|c|c|c|}
\hline Object & $\begin{array}{l}\text { sugar } \\
\text { transported }\end{array}$ & $\begin{array}{c}\text { flux rate } \\
\mu \text { moles } \mathrm{m}^{-2} \mathrm{~s}^{-1}\end{array}$ & $\begin{array}{c}\text { concentration } \\
\text { from which } \\
\text { transport occurs } \\
\text { mM }\end{array}$ & references \\
\hline $\begin{array}{l}\text { Abutilon } \\
\text { nectary trichomes }\end{array}$ & sucrose & $\begin{array}{l}\text { between } 0.6 \\
\text { and } 110^{\mathrm{a}}\end{array}$ & $500-1000^{\mathrm{b}}$ & $\begin{array}{l}\text { FINDLAX and MERCER, } \\
\text { 1971; GUNNING and } \\
\text { HUGHES, } 1976\end{array}$ \\
\hline $\begin{array}{l}\text { Vicia faba } \\
\text { leaves, phloem loading }\end{array}$ & sucrose & 0.14 & $?$ & GunNivg et al., 1974 \\
\hline $\begin{array}{l}\text { Allium cepa } \\
\text { onion epidermis }\end{array}$ & glucose & 0.03 & 230 & $\begin{array}{l}\text { STEINBRECHER and } \\
\text { LüTTGE, } 1969\end{array}$ \\
\hline $\begin{array}{l}\text { Zea mays } \\
\text { scutellum }\end{array}$ & sucrose & 0.125 & $>200^{c}$ & HuMpHREYs, 1973 \\
\hline Hydrodictyon africanum & glucose & $\begin{array}{l}0.007 \\
0.028 \\
0.042\end{array}$ & $\begin{array}{l}0.1 \\
1 \\
10\end{array}$ & Raven, 1976 \\
\hline \multirow[t]{2}{*}{ Nitella flexilis } & & $\begin{array}{l}0.01 \\
0.06\end{array}$ & $\begin{array}{l}1 \\
8\end{array}$ & WALLEN, 1974 \\
\hline & sucrose & $\begin{array}{l}0.005 \\
0.03\end{array}$ & $\begin{array}{l}1 \\
8\end{array}$ & \\
\hline Nitella translucens & glucose & 0.025 & 5 & Sмітн, 1967 \\
\hline Chlorella vulgaris & 6-deoxyclucose & 0.42 & 10 & TANNER et al., 1974 \\
\hline Neurospora crassa & glucose & $0.5^{\mathrm{d}}$ & $1^{\mathrm{d}}$ & $\begin{array}{l}\text { SLAYMAN and } \\
\text { SLAYMAN, } 1974\end{array}$ \\
\hline Saccharomyces cerevisiae & glucose & 1 & c & $\begin{array}{l}\text { KoTYK, } 1967 \text {, and per- } \\
\text { sonal communication }\end{array}$ \\
\hline
\end{tabular}

a) Taken from Figure 1 .

b) Assumed on the basis of a $18-30 \%$ sucrose solution supplied to the nectary gland via the phloem.

c) The rate given represents a $V_{\max }$ value of the transport system.

d) At the extreme and at high sugar concentration an occasionally observed maximum of total glucose influx may be $2 \mu$ moles $\mathrm{m}^{-2} \mathrm{~s}^{-1}$ (C. SLAYMAN, personal communication). 


\section{1. - Nectary phosphatases: Vectorial group transfer reactions mediated} by membrane-boud enzyme systems?

Nectary tissues stain heavily in the histochemical Gomori-test of acid phosphatases. This staining was considered as a pre-requisite for genuine secretory nectary gland tissue (ZIEgLER, 1956; Frey-WyssLing and HÄUSERMaNN, 1960). Phosphatases are often found in particular at or in the vicinity of the plasmalemma (FIGren 1968, 1972). These observations have led to speculations on a possible role of phosphorylations and dephosphorylations during active membrane passage of sugars in nectar secretion (e.g. LüTTGE, 1966). In membrane vesicles (ghosts) of facultatively anaerobic bacteria KABACK and coworkers (KABACK, 1970 a, b) indeed could demonstrate a molecular mechanism by which glucose is transported across a membrane with a vectorial group transfer reaction involving phosphorylation via PEP (= phosphoenol pyruvate). The principle of such vectorial group transfer reactions leading to membrane transport is shown in Figure 2. This graph is based on investigations of sucrose transport in sugar-cane and in the maize scutellum (Glasziou and Gayler, 1972; Humphreys, 1973; see revicw by LüTTGE and SCHNEPF, 1976).

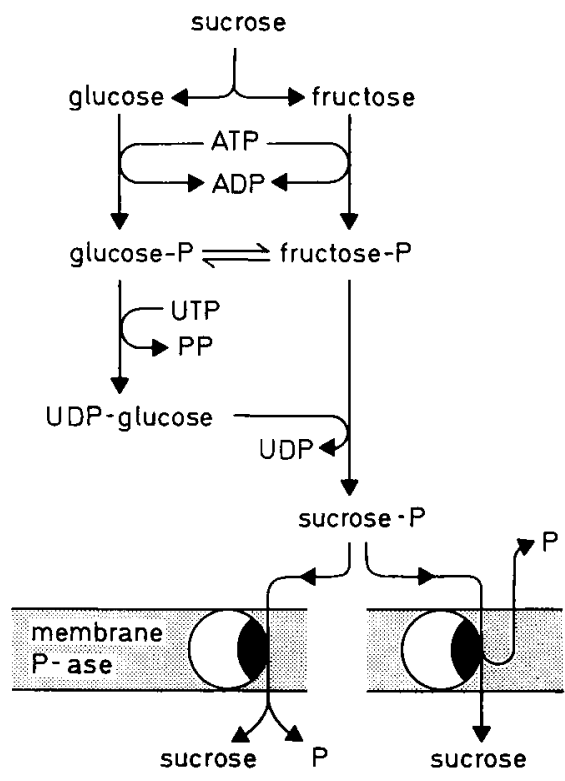

FIg. 2. - Schemes of sucrose transport across a membrane mediated by a membrane phosphatase catalysing " vectorial group transfer ».

It is possible that a mechanism of sugar passage across membranes of the kind shown in Figure 2 is also operative in nectar secretion. The alternative shown at the lower left of Figure 2 appears to be ruled out by the very low 
phosphate/sugar ratios observed in nectar (table 2). However, if reabsorption of phosphate occurs into the nectary cells during secretion this alternative remains a possibility. In any case, the alternative mechanism of the lower right of Figure 2 could be operative.

TABLE 2. - Non-sugar compounds in the nectar.

\begin{tabular}{|c|c|c|}
\hline $\begin{array}{l}\text { substance or } \\
\text { class of compounds }\end{array}$ & $\begin{array}{l}\text { amount per } 1 \mathrm{~g} \\
\text { of sugar in the nectar }\end{array}$ & references \\
\hline $\begin{array}{l}\text { amino acids } \\
\text { proteins }\end{array}$ & $\begin{array}{l}0.5-19.6 \mathrm{mg} / \mathrm{g} \\
0.02 \mathrm{mg} / \mathrm{g}\end{array}$ & $\begin{array}{l}\text { LüTTGE, 1961, 1966; LüTTGE and SCHNEPF, } \\
1976 ; \text { recently stressed by BAKER and } \\
\text { BAKER, } 1973 \text { a, b, 1975, 1976 }\end{array}$ \\
\hline $\begin{aligned} & \operatorname{mineral} \text { ions : } \mathbf{K}^{+} \\
& \mathrm{Na}^{+} \\
& \mathrm{Ca}^{2+} \\
& \mathbf{M g}^{2+} \\
& \\
& \mathrm{PO}_{4}^{3-}\end{aligned}$ & 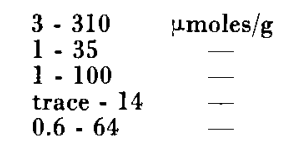 & $\begin{array}{l}\text { LÜTTGE, 1962, 1966; LёTTGE and SCHNEPF, } \\
1976\end{array}$ \\
\hline di- and tri-carboxylic acids & traces & 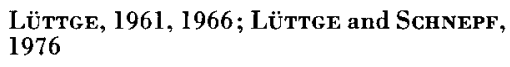 \\
\hline various vitamins & traces & $\begin{array}{l}\text { ZiEgLeR et al., 1964; LÜTTGE, 1966; } \\
\text { LüTTGE and SCHNEPF, } 1976\end{array}$ \\
\hline lipids & & BAKER and BAKER, 1975 \\
\hline antioxidants, e.g. ascorbate & $0.3-6.9 \mathrm{mg} / \mathrm{g}$ & $\begin{array}{l}\text { ZiEgLER et al, 1964; BAKER and BAKER, } \\
1975\end{array}$ \\
\hline $\begin{array}{l}\text { unfavourable constituents, e.g. } \\
\text { glucosides, alkaloids }\end{array}$ & & BAKER and BAKER, 1975 \\
\hline
\end{tabular}

The problem which remains and which makes these considerations speculations only, concerns the specific cytological localization and the chemical specificity of the dephosphorylating and phosphorylating enzymes. P-transfer enzymes are numerous and ubiquitous at cellular membranes in plant cells in general and in nectary gland cells in particular. HeinRich (1975) demonstrated histochemically the presence of $\beta$-glycerophosphatase, ATPase, nucleoside diphosphatase, and glucose-6-phosphatase at various membranes and in various organelles of Aloe nectaries. Quantitatively it appeared that enzyme activities were particularly high at the ER membranes and frequently absent at the plasmalemma. It remains very difficult to allocate a specific enzyme to a specific transport mechanism at a specific site in nectar secretion. 


\section{2. - Chemi-osmotic coupling to $\mathrm{H}^{+}$-electro-chemical gradients?}

The work of Komor and TANner (1971) shows that sugar molecules need not be phosphorylated during active membrane transport in Chlorella. As depicted in Figure 3 ATP hydrolysis can establish $\mathrm{H}^{+}$electro-chemical

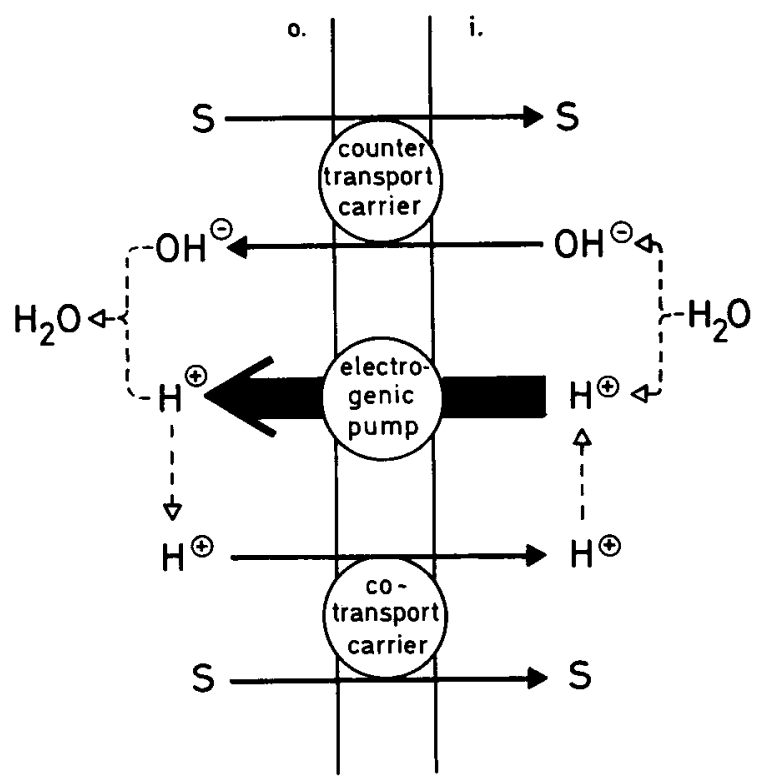

FIG. 3. - Chemi-osmotic coupling by counter-transport or co-transport utilizing the energy of an electro-chemical potential gradient established by an electrogenic $H^{+}$-pump. $\mathrm{o}=$ outside, $i=$ inside of cell.

gradients across membranes. By $\mathrm{H}^{+}$-sugar cotransport or $\mathrm{OH}^{-}$-sugar countertransport this gradient can be utilized for active membrane passage of sugar. Several predictions of this model can be tested experimentally. Firstly, the ATPase shown in Figure 3 acts as an electrogenic $\mathrm{H}^{+}$ion pump. The electrical membrane potential should be depolarized when the pump is not operating. A reversible depolarization of membrane potential by inhibitors of metabolic energy turnover stopping the energy supply for the pump has been now demonstrated for many higher plant cells (e.g. Higrnotrнaм et al., 1970; Anderson et al., 1974; Fischer et al., 1976). Secondly, as active sugar transport sets in the electro-chemical gradient driving it should be reduced at least initially, i.e. before increased metabolic energy supply for the pump begins to restore the gradient. A depolarization of membrane potential or a change of $\mathrm{pH}$ gradients or both has been observed in bacteria, in yeast, in the fungus $\mathrm{Neu}$ rospora crassa and in the unicellular alga Chlorella when transportable sugar was added (West, 1970; West and Mitchell, 1972, 1973; Seaston et al., 1973; 
Slayman and Slayman, 1974; Komor, 1973; Komor and Tanner, 1974 a, b; TANNer et al., 1974, 1977). Evidence that a similar mechanism is also operative in higher plants was obtained by Jones et al. (1975) with root cells of Impatiens balsamina. The membrane potential of these cells was depolarized significantly after the addition of glucose but not after the addition of the non-transported $\mathrm{C}_{6}$-alcohol sorbitol (fig. 4). More recently indications for a

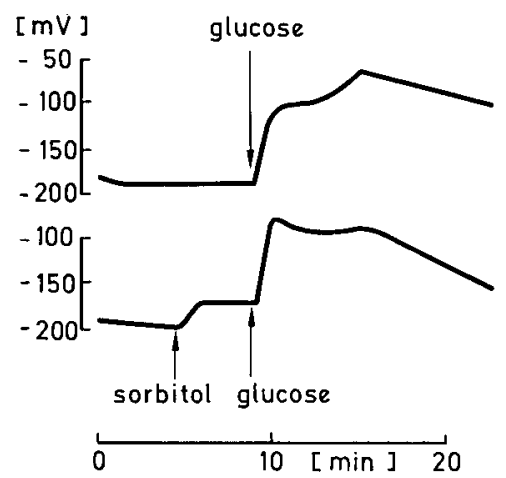

FIG. 4. - Depolarization of the membrane potential of Impatiens balsamina root cells by the addition of $50 \mathrm{mM}$ glucose but not $50 \mathrm{mM}$ sorbitol. (After Jones et al., 1975.)

sucrose- ${ }^{+}$cotransport have been observed in work with Ricinus cotyledons (Hutchings, 1976; see also “ conclusions 》 in TANner et al., 1977) and during phloem loading from the hollow petioles of adult Ricinus leaves (MALEK and Baker, 1977). In our own laboratory Novacky and Ullrich-Eberius found correlations between membrane potential and active glucose transport in fronds of the angiosperm water plant Lemna gibba (fig. 5). We have also attempted to find evidence for $\mathrm{H}^{+}$-sucrose cotransport during nectar secretion in Abutilon. Secretory cells are very small, and nobody sofar has reported insertions of glass microelectrodes and intracellular measurements of membrane potential. In our experiments we pipetted $180 \mu \mathrm{l}$ of $0.1 \mathrm{mM} \mathrm{CaSO}$ solution of pH 6.5 into the calyx of Abutilon flowers where the corolla was removed. We followed the $\mathrm{pH}$ change in the non-buffered $\mathrm{CaSO}_{4}$-solution over $24 \mathrm{~h}$ using Transidyne $\mathrm{pH}$ microelectrodes (No. 801). Sugar secreted into the $\mathrm{CaSO}_{4^{-}}$ solution by the nectaries on the bottom of the calyx was measured colorimetrically, corrections for volume changes of the $\mathrm{CaSo}_{4}$-solution during the experiment were made, and total sugar secreted was related to the $\mathrm{pH}$-change of the solution. In a few experiments we obtained good correlations between sugar secretion and apparent $\mathrm{H}^{+}$secretion, allowing speculations on operation of a sugar- $\mathrm{H}^{+}$-cotransport mechanism during nectar secretion (e.g. fig. 6). In other experiments we failed to reproduce this result. The reasons for this are not clear to us at present. They may be given by the complexity of the 
nectar secretion system. Furthermore, in order to obtain good results, Lemna had to be starved in darkness and with no sugar in the medium for several days before the experiments (fig. 5). Such an approach is not possible in nectar secretion studies with Abutilon flowers. Nevertheless, the results obtained so far (fig. 6) encourage to continue this work.

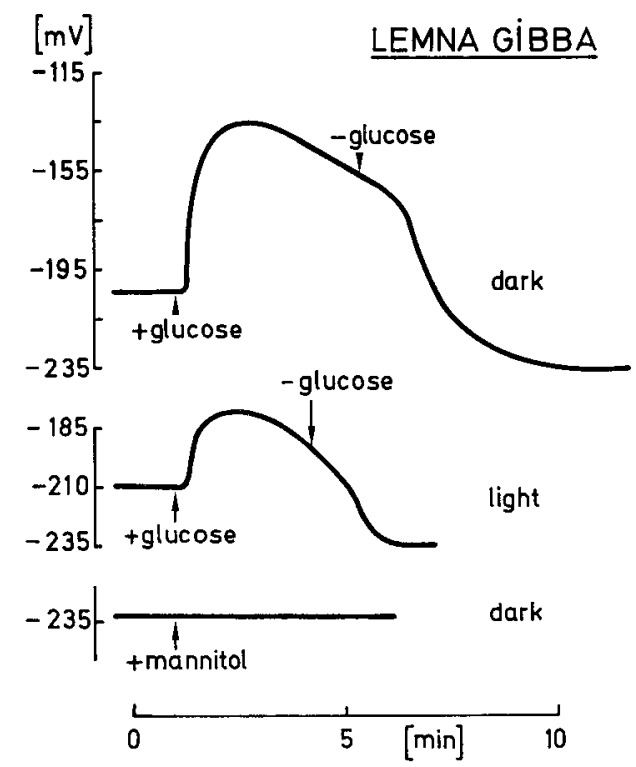

Fig. 5. - Depolarization of the membrane potential of dark grown sugar starved Lemna gibba (strain $G_{1}$ ) cells by $20 \mathrm{mM}$ glucose but not $20 \mathrm{mM}$ mannitol. Spontaneous recovery of membrane potential and recovery after glucose removal are more pronounced in the light than in the dark, suggesting additional photosynthetic energy supply. (Unpublished results of Novacky and Ullrich-Eberius.)

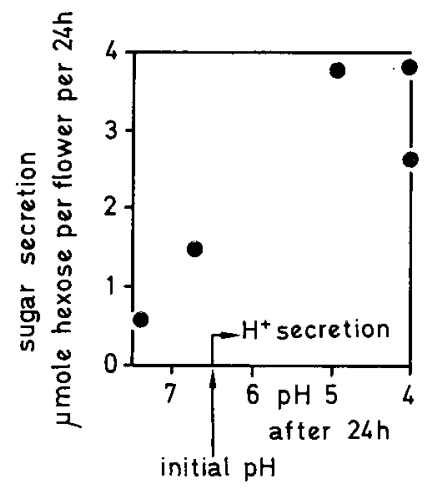

FIG. 6. - Correlation between sugar secretion and apparent $H^{+}$secretion by Abutilon nectaries. (From unpublished work of Novacky and Lüttge.) 


\section{3. - THE CHEMICAL COMPOSITION OF NECTAR}

The nectar chemically is a very specific secretion. Sugars make up about $90 \%$ of the total dry weight as seen in the following tabulation of an analysis of banana nectar (Musa sapientum) (LüTTGE, 1961) :

$\begin{array}{lrlll}\text { water } & 68 \% & \text { amino acids } & 0.014 & \% \\ \text { glucose } & 8 \% & \text { proteins } & 0.28-0.59 \% \\ \text { fructose } & 8 \% & \text { inorganic phosphate } & 0.032 & \% \\ \text { sucrose } & 16 \% & \text { organic phosphate } & 0.013 \%\end{array}$

There is a large spectrum of additional compounds, but these are present in the nectar only in minor quantities (table 2).

\section{1. - Specific sugar elimination in relation to the secretion mechanism}

The rather specific sugar elimination most easily can be explained by specific and active transport of sugar at one of the membrane sites in the secretory gland system as discussed in section 2 and by ScHnepF in the preceding review. Additional compounds associated with sugar in the nectar might be lost from the gland tissue only by passive diffusion. This is supported by an old finding of the author, i.e. that the amount of (c associate compounds ) in the nectar, such as aminoacids, depends on structural organization of the nectary gland. Primitive glands where the nectar passes through modified stomata or where lysigenous secretion occurs have much lower sugar/amino acid ratios in their nectar than highly developed glands with distinct secretory epithelia, trichomes or gland hairs (LüTTGE, 1961).

If different secretory mechanisms are assumed to operate, other possibilities must be envisaged to explain specificty of nectar composition. When nectar is secreted by a pressure flow mechanism (i.e. a volume pressed out by turgor) specific membrane transport mechanisms must operate for reabsorption of non-sugar compounds (ZiEgler, 1965). The same could be the case in granulocrine secretion when the secretion vesicles carry bulk cytoplasmic contents. Alternatively, the solution in the secretion vesicles might already have a specific composition as a result of specific sugar transport mechanisms in the endomembrane system before secretion, or due to an adjustment of prenectar composition during compartmental symplastic transport as suggested by GunNing and Hughes (1976).

\section{2. - Evolution of specific amino acid secretion mechanisms?}

A differentiation of secretory tissues which is obviously anatomically advanced leads to high sugar/amino acid ratios in the nectar, i.e. relatively 
low amounts of amino acids (see above; LÜTTGE, 1961). This somehow implies an evolution from primitive to advanced nectaries and from high amounts to low amounts of amino acids in the nectar. Ferns, e.g. Pteridium aquilinum and Photinopteris speciosa, are probably the evolutionarily lowest plants having nectaries (LüTTGE, 1960, 1961). These nectaries apparently are anatomically primitive. In $P$. aquilinum and $P h$. speciosa secretion occurs via modified stomata, and in $P$. aquilinum there is a high amount of amino acids in the nectar. An evolution towards more specialized nectaries and low diffusive and passive losses of amino acids into the nectar would appear plausible on the basis of the sap valve hypothesis. This hypothesis attempts a teleological explanation of the usefulness of nectar secretion, especially in the many cases of extrafloral nectaries where nectar does not serve pollination. According to this hypothesis secretion serves disposal of surplus sugar from the phloem sap in the vicinity of rapidly developing organs where the relatively low amounts of aminoacids and other $\mathrm{N}$-compounds supplied via the phloem are preferentially used for protein synthesis (ZIEGLER, 1965). A pertinent analog to this is the production of honey dew by phloem feeding aphids. However, the evolutionary aspect of this story is not clear. Although some of the most highly differentiated glands are found in flowers, angiosperms also have anatomically primitive nectar glands particularly as extrafloral nectaries. Furthermore nectaries most likely have evolved polyphyletically. A survey comparing the state of evolutionary advancement of plant species with the anatomical differentiation of their nectaries is not available. It might be rewarding to compile it from the large older literature on nectary gland anatomy.

By contrast to what we would expect on the basis of our comparison of nectary gland anatomy and sugar/amino acid ratios of nectar, BAKER and BAKER $(1973 \mathrm{a}, \mathrm{b}, 1975,1976)$ argue that there is a trend for evolution towards higher amino acid contents. These authors investigated various classes of pollination systems. The lowest amino acid content was found in the nectar of bee flowers. This appeared understandable, since bees also utilize pollen and thus have no problems with nitrogen supply. The highest amino acid contents were observed in nectar of flowers attracting dung flies. Intermediate values were found for butterfly flowers. In the nectars of butterfly flowers there were increasing amounts of amino acids and increasingly complex spectra of various amino acids with increasing evolutionary advancement of the respective plant species. Amino acids may be important in the diet of butterflies. Thus, the development of specific amino acid transport mechanisms in nectar secretion may play a role in co-evolution of such specialized pollinator systems.

In comparison with the anatomical relationship leading to lower amino acid elimination by diffusive loss as structure is advanced, this development 
of amino acid secretion presumably would be a more recent evolutionary trend. The finding of BAKER and BAKER, that amino acid spectra in the nectar of particular plants can be very specific, stresses the suspicion that rather specific transport mechanisms must be involved. Amino acid spectra within plant cells invariably are much less specific and comprise most of the proteinogenous amino acids. Clearly, new work is needed now, in particular on amino acid secretion mechanisms in various nectary glands.

Received in April 1977.

\section{ACKNOWLEDGEMENT}

I am particularly indepted to my colleagues Cornelia ULtrich-Frerius and Anton Novacky for supplying the experimental data of Figures 5 and 6 . John Raven and Clifford Slayman kindly helped compiling the data of Table 1 . Our own experiments were supported by the Deutsche Forschungsgemeinschaft.

\section{ZUSAMMENFASSUNG}

\section{ZUSAMMENSETZUNG DES NEKTARS UND MEMBRANTRANSPORT VON ZUCKER UND AMINOSÄUREN : EIN BERICHT ÜBER DEN GEGENW ÄRTIGEN STAND DER NEKTARFORSCHUNG}

Dieses Übersichtsreferat vergleicht zunächst die Raten des aktiven Membrantransportes von Zucker bei der Nektarsekretion mit dem Zuckertransport in anderen pflanzlichen Zellen und Geweben. Zwei mögliche Mechanismen des Zuckermembranstransportes werden besprochen, nämlich vektorielle Gruppenübertragungsreaktionen durch membrangebundene Phosphatasen und die chemi-osmotische Kopplung mit $\mathrm{H}^{+}$-elektrochemischen Gradienten. Die chemische Zusammensetzung des Nektars wird im Hinblick auf den Sekretionsmechanismus diskutiert, der zur spezifischen Zuckerausscheidung führen muß. Hinweise für die mögliche Evolution spezifischer Aminosäuresekretionsmechanismen werden referiert.

\section{RÉSUMÉ}

COMPOSITION DU NECTAR ET TRANSPORT MEMBRANIQUE DES SUCRES ET DES ACIDES AMINÉs : UNE MISE AU POINT SUR L'ÉTAT ACTUEL DE LA RECHERCHE SUR LE NECTAR

Cette mise au point compare les vitesses de transport membranique actif des sucres au cours de la sécrétion nectarifère avec les flux de sucre dans d'autres systèmes de plantes. Les mécanismes possibles du transport membranique des sucres sont évalués, principalement les réactions de transfert vectoriel de groupe par les phosphatases liées à la membrane et par le couplage chimi-osmotique avec les gradients électrochimiques $H^{+}$. On discute de la composition 
chimique du nectar en relation avec le mécanisme de sécrétion qui conduit à l'élimination spécifique de sucres et aussi en relation avec l'évolution possible des mécanismes spécifiques de sécrétion des acides aminés.

\section{REFERENCES}

Anderson W. P., Hendrix D. L., Higinbotham N., 1974. - The effect of cyanide and carbon monoxide on the electrical potential and resistance of cell membranes. Plant Physiol., 54, 712-716.

BaKer H. G., BaKer I., 1973 a. - Amino-acids in nectar and their evolutionary significance. Nature, 24I, 545.

BAKER H. G., BAKER I., 1973 b. - Some anthecological aspects of the evolution of nectarproducing flowers, particularly amino acid production in nectar. In HEYwood, U. H. (ed.) Taxonomy and ecology. Academic Press, London.

BAKER H. G., BAKEr I. 1975. - Studies of nectar-constitution and pollinator-plant coevolution. In Gilbert, L.E. and Raven, P. H. (eds.) Coevolution of animals and plants University of Texas Press, Austin.

BaKer H. G., BaKer I., 1976. - Analyses of amino acids in flower nectars of hybrids and their parents with phylogenetic implications. New Phytol., 76, 87-98.

Brewer J. W., Colly ard K. J., LotT C. E., 1974. -- Analysis of sugars in dwarf mistletoe nectar. Can. J. Bot., 52, 2533-2538.

Figrer J., 1968. - Localisation infrastructurale de la phosphomonoestérase acide dans la stipule de Vicia faba L. au niveau du nectaire. Rôles possibles de cet enzyme dans les mécanismes de la sécrétion. Planta, 83, 60-79.

Figier J., 1972. - Localisation infrastructurale de la phosphatase acide dans les glandes pétiolaires d'Impatiens holstii : rôles possibles de cette enzyme au cours des processus sécrétoire. Planta, 108, 215-226.

Findlay N., Mercer F. V., 1971. - Nectar production in Abutilon. I. Movement of nectar through the cuticle. Australian J. Biol. Sci., 24, 647-656.

Findeay N., Reed M. L., Mercer F. V., 1971. - Nectar production in Abutilon. III. Sugar secretion. Australian J. Biol. Sci., 24, 665-675.

Fischer E., Lürtge U., Higinbotham N., 1976. - Effet of cyanide on the plasmalemma potential of Mnium. Plant Physiol., 58, 240-24.1.

Frey-Wyssuing A., u. Häusermann E., 1960. - Die Deutung der gestaltlosen Nektarien. Ber. Schueiz. Botan. Ges., 70, 150-162.

Glasziou K. T., Gayler K. R., 1972. - Storage of sugars in stalks of sugar cane. Botan. Rev., 38, 471-4,90.

Gunning B. E. S., Hugnes J. E., 1976. - Quantitative assessment of symplastic transport of pre-nectar into the trichomes of Abutilon nectaries. Aust. J. Plant Physiol., 3, 619637.

Gunning B. E. S., Pate J. S., Minchin F. R., Marks I., 1974. - Quantitative aspects of transfer cell structure in relation to vein loading in leaves and solute transport in legume nodules. Symp. Soc. exp. Biol., 28, 87-126.

Heinrich G., 1975. - Ủber die Lokalisation verschiedener Phosphatasen im Nektarium von Aloë. Cytobiologie, 11, 247-263.

Higinbotham N., Graves J. S., Davis R. F., 1970. - Evidence for an electrogenic ion transport pump in cells of higher plants. J. Membr. Biol., 3, 210-222.

Humphreys T. E., 1973. - Sucrose-transport at the tonoplast. Phytochem., 12, 1211-1219.

Hutchings V. M., 1976. - Sucrose and proton co-transport in Ricinus cotyledons. Ph.-D. Thesis, Cambridge, England.

Jones M. G. K., Novacky A., Dropkin V. H., 1975. - Transmembrane potentials of parenchyma cells and nematode-induced transfer cells. Protoplasma, 85, 15-37. 
KABACK H. R., 1970 a. - The transport of sugars across isolated bacterial membranes. In Bronner F., and Kleinzeller A. (eds.) Current topics in membranes and transport, vol. 1., Academic Press, New York-London.

KabaCK H. R., 1970 b. - Transport. Annu. Rev. Biochem., 39, 561-598.

Komor E., 1973. - Proton-coupled hexose transport in Chlorella vulgaris. F.E.B.S.-Letters, 38, $16-18$.

Komor E., TANner W., 1971. - Characterisation of the active hexose transport system of Chlorella vulgaris. Biochim. Biophys. Acta, 241, 170-179.

Komor E., TANner W., 1974 a. - The hexose-proton cotransport system of Chlorella. pHdependent change in $K_{m}$ values and translocation constants of the uptake system. $J$. Gen. Physiol., 64, 568-581.

Komor E., Tanner W., 1974 b. - The hexose proton symport system of Chlorella vulgaris. Specificity, stoichiometry and energetics of sugar-induced proton uptake. Eur. J. Biochem., 44, 219-233.

KotyK A., 1967. - Properties of the sugar carrier in baker's yeast. II. Specifiticy of transport. Fol. microbiol., (Praha) 12, 121-131.

LütTge U., 1960. - Die Zusammensetzung des Nektars und der Mechanismus seiner Sekretion. Dr. rer. nat.-Thesis, Darmstadt, Germany.

LüTtGe U., 1961. - Über die Zusammensetzung des Nektars und den Mechanismus seiner Sekretion. I. Planta, 56, 189-212.

LütTgE U., 1962. - Über die Zusammensetzung des Nektars und den Mechanismus seiner Sekretion. II. Mitteilung. Der Kationengehalt des Nektars und die Bedeutung des Verhältnisses $\mathrm{Mg}^{++} / \mathrm{Ca}^{++}$im Drüsengewebe für die Sekretion. Planta, 59, 108-114.

LütTge U., 1966. - Funktion und Struktur pflanzlicher Drüsen. Naturwissenschaften, 53, 96-103.

LütTge U., Schnepf E., 1976. - Elimination processes by glands : Organic substances. In Lütrge. U., and Pitman M. G. (eds.) Transport in Plants II Part B : Tissues and Organs. Encyclopedia of Plant Physiology New Series vol. 2, Spirnger-Verlag, BerlinHeidelberg-New York.

M ALEK F., BaKer D. A., 1977. - Proton co-transport of sugars in phloem loading. Planta, 135, 297-299.

Raven J. A., 1976. - Active influx of hexose in Hydrodictyon africanum. New Phytol., 76, 189-194.

Seaston A., Inkson C., Eddy A. A., 1973. - The absorption of protons with specific amino acids and carbohydrates by yeast. Biochem. J., 134, 1031-1043.

Slayman C. L., Stayman C. W., 1974. - Depolarization of the plasma membrane of Neurospora during active transport of glucose : evidence for a proton-dependent cotransport system Proc. Nat. Acad. Sci. U.S.A., 71, 1935-1939.

Sмrтн F. A., 1967. - Links between glucose uptake and metabolism in Nitella translucens. J. exp. Bot., 18, 348-358.

Steinbre cher W., Lüttge U., 1969. - Sugar and ion transport in isolated onion epidermis. Australian J. Biol. Sci., 22, 1137-1143.

Tanner W., Haass D., Decker M., Loos E., Komor B., Komor E., 1974. - Active hexose transport in Chlorella vulgaris. In ZimmermanN U. and DaINTY J. (eds.) Membrane transport in plants. Springer-Verlag, Berlin-Heidelberg-New York.

Tanner W., Komor E., Fenze F., Decker M., 1977. - Sugar-proton cotransport systems. In MARRE E. and CIfERri O. (eds.) Regulation of cell membrane activities in plants. NorthHolland Publishing Company, Amsterdam-Oxford-New York .

Wallen D., 1974. - Glucoce, fructose, and sucrose influx into Nitella flexilis. Can. J. Bot., 52, $1-4$.

WEST I. C., 1970. - Lactose transport coupled to proton movements in Escherichia coli. Biochem. Biophys. Res. Commun., 41, 655-661.

West I. C., Mitchell P., 1972. - Proton-coupled B-galactoside translocation in non-metabolizing Escherichia coli. J. Bioenerg., 3, 445-462.

West I. C. Mrtchell P. 1973. - Stoichiometry of lactose-H ${ }^{+}$symport across the plasma membrane of Escherichia coli. Biochem. J., 123, 587-592. 
Ziegler H., 1956. - Untersuchungen über die Leitung und Sekretion der Assimilate. Planta, 47, $4.47-500$.

Ziegler H., 1965. - Die Physiologie pflanzlicher Drüsen. Ber. Deut. Botan. Ges., 78, 466-477.

Ziegler H., Lüttge U., u. Lüttge U., 1964. - Die wasserlöslichen Vitamine des Nektars. Flora, 154, 251-229.

ZimmermanN M. H., 1954. Ùber die Sekretion saccharosespaltender Transglucosidasen im pflanzlichen Nektar. Experientia, 10, 145-146.

\section{NOTE ADDEDIN PROOF}

After submission of the manuscript three more publications appeared, which demonstrate $\mathrm{H}^{+}$-sugar cotransport in angiosperms :

Giaquinta R., 1977. - Phloem loading of sucrose. pH dependence and selectivity. Plant Physiol. 59, 750-755.

Komor E., Rotter M., TANNer W., 1977. - A proton-cotransport system in a higher plant : sucrose transport in Ricinus communis. Plant Science Letters 9, 153-162.

Racusen R. H., GaLston A. W., 1977. -- Electrical evidence for rhythmic changes in the cotransport of sucrose and hydrogen ions in Samanea pulvini. Planta 135, 57-62.

One paper appeared which relates structure of floral nectaries to phylogeny of the order Centrospermales :

Zandonella P., 1977. - Apports de l'étude comparée des nectaires floraux à la conception phylogénétique de l'ordre des Centrospermales. Ber. Deut. Botan. Ges. 90, 105-125. 